\title{
O lugar da História da Arte no Brasil: breve revisão da instituição da história da arte no Brasil a partir dos cursos de graduação*
}

EL LUGAR DE LA HISTORIA DEL ARTE EN BRASIL: BREVE REVISIÓN

DE LA INSTITUCIONALIZACIÓN DE LA HISTORIA DEL ARTE EN

BRASIL A PARTIR DE SUS PROGRAMAS DE PREGRADO.

THE PLACE OF ART HISTORY IN BRAZIL: A BRIEF REVIEW

OF THE INSTITUTION OF ART HISTORY IN BRAZIL FROM ITS

UNDERGRADUATE COURSES

\section{Danielle Amaro**}

Cuadernos de Música, Artes Visuales y Artes Escénicas

/ Volumen 9 - Número 1 / Enero - Junio de 2014

/ ISSN 1794-6670/ Bogotá, D.C., Colombia / pp. 69-93

Fecha de recepción: 7 de diciembre de 2013 | Fecha de aceptación: 26 de febrero de 2014. Encuentre este artículo

en http://cuadernosmusicayartes.javeriana.edu.co/

doi:10.11144/Javeriana.MAVAE9-1.olha

* Este documento proviene de la investigación llevada a cabo para la realización del trabajo de doctorado en Historia Social de la Universidade de São Paulo, Brasil.

** Máster en Artes de la Universidade Estadual de Campinas (Unicamp, 2008-2010), estudiante de doctorado en Historia Social de la Universidade de São Paulo (Usp, 2013). Trabaja en el Programa de Inclusión Sociocultural del Núcleo de Acción Educativa de la Pinacoteca del Estado de São Paulo. 


\section{Resumo}

O artigo apresenta uma breve revisão histórica da instituição da história da arte no Brasil a partir do exame das circunstâncias de implantação e amadurecimento dos cursos de graduação nesta área, refletindo assim sobre a formação do historiador da arte neste contexto em particular. O artigo apresenta as questões e argumentos iniciais do projeto de pesquisa "História da Arte no Brasil: lugar e cientificidade" que atualmente desenvolvo em minha pesquisa de doutorado. Supõe-se que a criação de cursos de graduação em história da arte emerge como processo de legitimação e consolidação de uma comunidade científica (por isso, rico em controvérsias e consensos) que, no Brasil, se manteve disperso durante muito tempo entre outros campos de investigação.

Palavras-chaves: história da Arte; história da arte no Brasil; a formação do historiador da arte brasileiro; graduações em história da arte em universidades brasileiras; história da ciência

Palavras-chave descritor: arte-estudo e ensino; currículos; arte nas universidades e faculdades; Brasil

\section{Resumen}

El artículo presenta una breve revisión histórica de la institución de la historia del arte en Brasil, que surge al examinar las circunstancias en las que se implantaron y maduraron los cursos de pregrado en historia del arte, reflexionando sobre la formación del historiador de arte en este contexto en particular. El artículo presenta las preguntas y argumentos iniciales del proyecto de investigación "História da Arte no Brasil: lugar e cientificidade" que desarrollo actualmente en mi investigación de doctorado. Se supone que la creación de cursos de pregrado en historia del arte emergen como proceso de legitimación y consolidación de una comunidad científica (por esta razón, está lleno controversias y consensos), el cual en Brasil se mantuvo diseminado durante mucho tiempo en medio de otros campos de investigación.
Palabras clave: historia del arte; historia del arte en Brasil; la formación del historiador del arte brasileño; pregrados en historia del arte en universidades brasileñas; historia de la ciencia

Palabras clave descriptores: historia del

arte; enseñanza de arte; planes de estudio universitario; Brasil

\section{Abstract}

This article presents a brief historical review of the establishment of Art History in Brazil from an exame of the circumstances of deployment and improvement of degree courses in Art History, thus reflecting on the formation of an art historian in this particular context. The article presents the issues and initial arguments of the research project "Art History in Brazil: place and scientificity", that I currently develop on my doctorate research. It is assumed that the creation of degree courses in art history emerges as a process of legitimization and consolidation of a scientific community (therefore, full of controversies and consensus) that in Brazil remained dispersed for a long time among other fields of study.

Keywords: art history; art history in Brazil; the formation of brazilian art historian; degree in art history at brazilian universities; science history Keywords Plus: art history; study and teaching; art curricula; universities and colleges; Brazil 
O novo historiador tem cada vez mais a consciência aguda de que a história é escrita

e escrita por ele, historiador. Ele escreve a história, é parte dela, e no momento em que a escreve constrói uma história a partir de certo padrão de narração, segundo uma forma. (...) O historiador trata dos eventos no presente, com sua armadura cultural, com sua estrutura epistemológica, conformando esse objeto. (...) A interpretação não se sobrepõe aos fatos. Os fatos, em si mesmos, são fatos interpretados. Quando se lê a história se lê um texto, é claro. O problema do narrar, o problema do escrever a história é um problema histórico. Obviamente não estou dizendo que inexista o real. Mas, quando o real se torna histórico e captado no interior de outra ordem, é efetivado na ordem da linguagem. Quando o historiador contemporâneo percebe que utiliza uma linguagem - linguagem que não é só verbo e escrita, é também um método, uma tática de pensamento, um projeto de compreensão - obriga-se a um comprometimento cultural.

(...) Mas, afinal, quem é o historiador? Aquele que sofre de paixão crônica pela realidade, mas é casado, querendo ou não, com a linguagem. (...) Os historiadores, felizmente, ficam perplexos ao saber que o fato histórico é fato interpretado, e interpretado também por eles mesmos: o problema da história tem início exatamente na relação do historiador com esse fato.

Ronaldo Brito ${ }^{1}$

\section{NOTAS INTRODUTÓRIAS: O QUE CHAMAMOS “HISTÓRIA DA ARTE"?}

Eu estou inscrita, eu me inscrevi nesse texto, deixei aí meu rastro². Inicio essas "notas introdutórias" retomando dois problemas de ordem historiográfica: a escrita (conteúdo e forma) e o lugar (escritor e contexto).

Segundo o historiador da arte alemão Hans Belting, a chamada "História da Arte" sempre foi uma "História da Arte européia", cuja escrita sempre esteve arraigada da cultura literária e científica produzidas nesse lugar, e que "apesar de todas as identidades nacionais, a hegemonia da Europa permanecia incontestada". No entanto, adverte: "essa bela imagem provoca hoje o protesto de todos aqueles que não se consideram mais representados por ela" (Belting, 2006, p.96). Para melhor explicitar a questão, Belting compreende a relação entre os fenômenos atribuídos como artísticos e a história da arte como um ajuste entre enquadrado e enquadramento, sendo o enquadrado o objeto de estudo da história da arte e, por sua vez, o enquadramento como a própria história da arte. Ambos, segundo o historiador, forjados em uma conjuntura particular e com finalidades muito específicas.

Belting considera o pretenso universalismo da história da arte como um equívoco ocidental fundamentado por uma visão eurocêntrica moderna. Enquanto uma invenção ocidental, a história da arte elegeu uma determinada produção imagética, ou seja, certas formas de 
arte como historicamente imperativas. O anúncio do "fim da história da arte", sobre o qual o historiador trata desde o princípio da década de 1980, emerge dos conflitos advindos entre enquadrado e enquadramento (com a perda das especificidades do objeto e da ausência de paradigmas, por exemplo). Ao contrário de significar que tudo acabou, aponta para a necessidade de uma mudança discursiva.

Aquela "História da Arte" que se pressupunha universal e que, por isso, pretendia a representação de todos os continentes e culturas, diluiu-se em meio a um número sem fim de reivindicações que partiram daqueles que não se sentiam representados por tal narrativa. $A$ "abertura" da cultura ocidental para a assimilação (à sua forma, logicamente) de outras culturas não pode acontecer ilimitadamente sem que haja prejuízos e lucros, perdas e ganhos para a antiga História da Arte. Não é um problema simples de "encaixe": as conseqüências são mais profundas.

A Professora Dra. Maria Lúcia Bastos Kern (PUC-RS), que desde pelo menos a década de 1980 tem se dedicado a reflexões sobre a historiografia da arte brasileira, trata do problema da suposta universalidade narrativa da história da arte e suas consequências na América Latina:

Esse modelo utilizado pela disciplina opera muitas exclusões, tornando difícil a compreensão da complexidade artística. (...) Os historiadores da arte, fora dos grandes centros cosmopolitas, nem sempre abordam a arte nas suas singularidades e especificidades culturais, mas focalizam seus estudos com o fim de verificar as mudanças ocorridas na periferia em relação aos centros de criação. Quando as práticas artísticas diferem são logo rotuladas como atrasadas, pois a historiografia se fundamenta no paradigma dominante, adotando seus cânones e valores como critérios de avaliação, os quais levam muitas vezes a desqualificação das obras em estudo. O paradigma dominante ao ser prestigiado se impõe como normativa, excluindo as criações que não se equiparam ao mesmo.

O modelo vinculado à ideologia universalista engendrou a necessidade de atualização e equiparação às matrizes européias e norte-americanas, como se os artistas não fossem, segundo esse olhar, detentores de poder de invenção ou de criações alternativas. Estas acepções estão ainda atreladas àquelas de evolução em direção ao progresso e à perfeição e de tempo linear, daí o eterno desejo de produção do novo e de equiparação às matrizes dos grandes centros. (Kern, 2004, pp. 207-208)

A partir de tal problemática, me coloco a questão: se, diferentemente do que pressupõe o senso comum, a História da Arte não é uma mera narração de fatos, e não pode ser transferida incólume para uma cultura na qual "falta" uma narrativa semelhante à européia, então o que significaria escrever história da arte no Brasil e, por consequência, qual o lugar por ela ocupado nesse contexto? Segundo Belting, "onde falta semelhante tradição, não é possível simplesmente inventar uma História da Arte de estilo europeu, procedendo-se de maneira análoga e na esperança de que surja algo semelhante" (2006, p. 97).

Obviamente, Belting problematiza a História da Arte a partir do seu lugar de discurso, enquanto historiador da arte, europeu, alemão, herdeiro dos cânones de uma ciência européia, que tem na história, na cultura e no meio científico germânicos os alicerces de suas fundações. No entanto, o mesmo não nos exime - a nós, não-europeus, ou seja, não-ocidentais, latino-americanos - da necessidade de uma tomada de posição a partir de um desafio: pensar a história da arte a partir do sul. 
Tendo em vista o contexto particular brasileiro, eu escolhi pensar a partir de um dos lugares de formação do historiador da arte, construindo uma história das histórias da arte tecidas nas universidades brasileiras. Considerando que eu estou imersa igualmente neste contexto, eu escrevo: logo eu interpreto por meio da escrita a partir de determinado lugar, deste lugar. E, ao mesmo tempo, sou inscrita, já que participo desta operação historiográfica, tal como formulada pelo historiador francês Michel de Certeau (2007), na qual se articulam o lugar, as práticas e os procedimentos, a escrita.

O texto que apresento é parte de um projeto, de uma intenção de fazer. Logo, é parte de um percurso ainda não percorrido. O intento é refletir sobre a escrita, a grafia da história da arte em seus ambíguos e complementares sentidos: como ela foi/é escrita (uma história das histórias da arte) e como projeto de escrita (teoria e métodos). Por ora, o que se pretende é esboçar um quadro geral a respeito da configuração do campo no Brasil a partir de uma revisão de alguns aspectos e momentos considerados por mim fundamentais para uma compreensão da configuração atual do campo.

\section{A FORMAÇÃO DO HISTORIADOR DA ARTE NO BRASIL}

No Brasil, atualmente são oferecidos cinco cursos de graduação, todos em universidades públicas, como pode ser observado no mapa e na figura 1.

A criação e implantação desses cursos acontecem em momentos diversos. Durante quase meio século, houve apenas um curso de graduação em História da Arte: aquele alocado na Universidade do Estado do Rio de Janeiro (UERJ) desde 1978 até os dias de hoje, mas que tem suas origens no extinto Instituto de Belas Artes da Guanabara, cujo ingresso da primeira turma deu-se em 1961. Depois de quase cinco décadas, no início do século XXI, são inaugurados os outros quatro cursos, oferecidos pela Universidade Federal do Rio de Janeiro (UFRJ), Universidade Federal de São Paulo (UNIFESP), Universidade Federal do Rio Grande do Sul (UFRGS) e Universidade de Brasília (UnB).

Apesar do espaço temporal existente entre o primeiro e os outros, uma característica os congrega: todos estão localizados no chamado Centro-Sul do país ${ }^{3}$. Nela há uma grande concentração populacional e de renda ${ }^{4}$, além de centros urbanos dotados de uma boa infraestrutura e oferta de serviços públicos e privados. Por exemplo: considerando particularmente a presença de equipamentos oficiais de cultura, no Centro-Sul se encontram as duas (das três) cidades brasileiras com maior número de museus e onde se concentram os maiores acervos: São Paulo/SP e Rio de Janeiro/RJ (a terceira cidade é Salvador/BA). No que tange a temática e a tipologia do acervo, pelo menos metade dos museus é de Artes Visuais. Tendo em vista o número total de empregados nos museus brasileiros, mais de $75 \%$ se vincula a instituições do Centro-Sul. Isso apenas para citar um dos vários possíveis campos de atuação para os profissionais formados em História da Arte.

A partir da explanação desse quadro mais geral, pretende-se tratar das particularidades contextuais dos dois momentos de criação e implantação dos cursos de graduação em História da Arte no Brasil. Para isso, é proposto dois recortes temporais: o primeiro momento entre as décadas de 1940 e 1970; e o segundo momento cujo marco inicial se dá em década de 1980 até os dias de hoje. Essa divisão usa como referência as particularidades dos discursos que se manifestam nas propostas de cursos nesses dois momentos distintos e, por conseguinte, o projeto de História da Arte que neles se inscreve, relacionando-os em um panorama mais geral. 


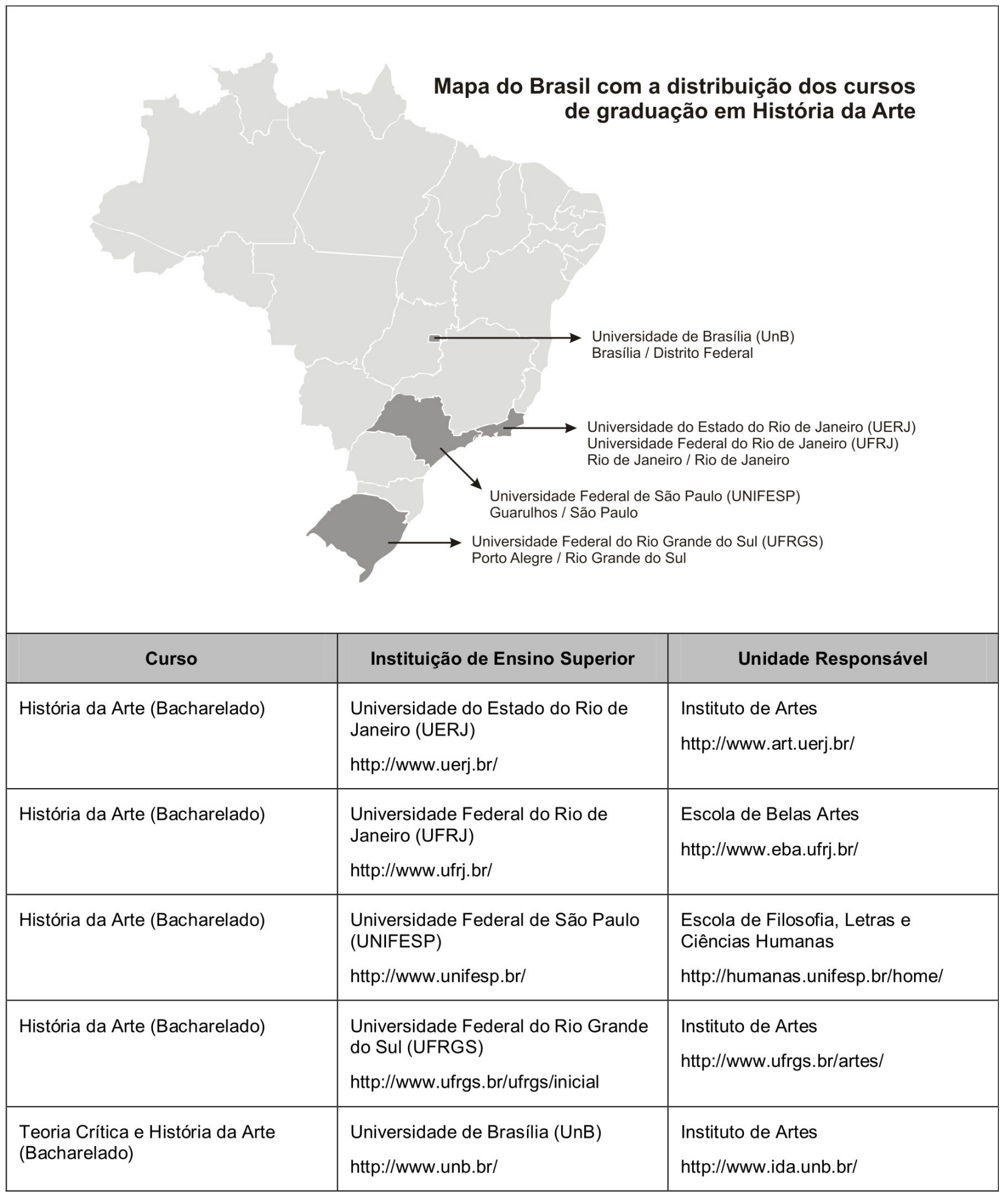

Figura 1. Mapa do Brasil com a distribuição geográfica dos cursos de graduação em História da Arte. Fonte: arquivo da autora 
O Curso Superior de História da Arte, o primeiro da área no Brasil (ao menos, de acordo com os documentos e artigos pesquisados até o momento), foi criado pela Secretaria de Cultura do Estado da Guanabara ${ }^{5}$. Oferecido pelo extinto Instituto de Belas Artes da Guanabara (IBA), segundo o decreto $\mathrm{n}^{0} 1.526$ de 12 de fevereiro de 1963, o curso, cujo ingresso da primeira turma deu-se em 1961, se destinava à formação de professores de História da Arte "para as atividades, áreas de estudo e disciplinas do Ensino de $1^{\circ}$ e $2^{\circ}$ Graus relacionados com o setor de Arte" (Processo UERJ 605/DAA/1980, Arquivo DEP/SR1, fl.06). A seleção dos candidatos se fazia mediante provas orais e escritas de Português; História Geral; Inglês ou Francês.

A criação do curso foi divulgada em diversos periódicos. Em 21 de fevereiro, poucos dias depois da publicação do já citado decreto n¹.526 (o qual aprovava "o novo regulamento do Instituto de Belas Artes do Estado da Guanabara"), na coluna "Vida das Artes" do jornal "Diário de Notícias" (o qual se auto-intitulava "o matutino de maior tiragem do Estado da Guanabara"), assinada naquele período pelo professor José Roberto Teixeira Leite, é publicado o artigo "A História da Arte no IBA", no qual o autor fala com entusiasmo da criação do curso:

Com a recente reforma levada a efeito no Instituto de Belas Artes do Estado da Guanabara, ganhou o Rio de Janeiro seu primeiro curso superior de História da Arte, destinado especificamente à formação de professores dessa disciplina, sob todos os aspectos fascinante. Antes, era a mesma ministrada em escolas de belas artes e em faculdades de Arquitetura e de Filosofia, mas não na profundidade que agora se pretende imprimir ao curso, com a contratação, inclusive, de mestres no exterior. (1963, p. 3)

$\mathrm{O}$ artigo é curto. Resume-se ao trecho transcrito e à publicação do currículo. Distribuídas ao longo de três anos, o curso superior de História da Arte constava das seguintes disciplinas: $1^{\circ}$ ano: História da Arte Antiga e Medieval; História da Cultura Contemporânea; Teoria da Percepção; $2^{\circ}$ ano: História da Arte do século XV ao século XVIII; História da Arte do Extremo Oriente (um semestre); Estética I; $3^{\circ}$ ano: História da Arte dos séculos XIX e XX; História da Arte no Brasil; História da Crítica de Arte; Estética II; Didática.

Alguns aspectos salientam-se na estrutura curricular do curso como, por exemplo, a perspectiva universalista da história da arte. A série de disciplinas dedicadas à História da Arte Universal (desde a Antiguidade até a produção artística do século XX) abarca períodos históricos extensos, organizados cronologicamente do mais antigo ao mais recente, com ênfase na produção artística e cultural européia.

É perceptível a existência de um segundo bloco de disciplinas nomeadas como "História da arte", mas que revelam a existência de outros fenômenos e narrativas particulares que não se enquadrariam nesta história universal, sendo necessária a criação de um contexto específico para a discussão delas. Seria assim o caso das disciplinas "História da Arte no Brasil" e "História da Arte do Extremo Oriente".

À História da Arte no Brasil é dedicada apenas uma disciplina. A produção latino-americana não é sequer citada em nenhum dos títulos ${ }^{6}$. Ao contrário do que acontece com a produção artística e cultural do "Extremo Oriente", a qual é dedicada uma disciplina exclusiva, não há qualquer indício na nomenclatura das disciplinas de uma discussão específica sobre a da África. Sobre esse fato em particular, o Professor Roberto Conduru (UERJ) esboça uma avaliação 
crítica interessante: "estruturado geopoliticamente, não há menção à África. A história da arte africana não era, portanto, considerada necessária à formação do historiador da arte no Brasil, fosse em si, ou como complemento da história da arte ocidental (...). Silêncio que deriva de uma hierarquia segundo a qual a arte nesse continente ocupa um dos níveis inferiores, se não o mais baixo, na escala de valores históricos e artísticos" (Conduru, 2007, p. 151).

Logo, não basta analisar aquilo que se encontra expresso oficialmente em palavras. Devese atentar para a existência de um currículo oculto, que se refere a discursos implícitos, propositais e não menos importantes do que os planos e propostas evidentes no currículo formal, e que são igualmente ensinados. Os processos de inclusão e exclusão de conteúdos, o que deve e o que não deve ser ensinado constituem igualmente o currículo. Além do discurso evidente nas nomenclaturas e ementas das disciplinas, as ausências e silêncios igualmente revelam um projeto de formação profissional e, principalmente, de história da arte muito próximo daquele criticado por Kern (como já citado anteriormente) fundamentado no paradigma eurocêntrico.

Não foram encontrados documentos que afirmem o reforço da marginalidade da produção artística de origem africana após o golpe de 1964. No entanto, alguns detalhes podem revelar uma conjuntura desfavorável para o desenvolvimento de um discurso crítico a respeito destes conteúdos.

Segundo Cunha e Góes, "baixado o Al-5 em dezembro de 1968, (...) a disciplina educação moral e cívica deveria, obrigatoriamente, integrar os currículos escolares de todos os graus e modalidades do sistema de ensino do país" (2002, p. 72). Sobre a sua presença no Ensino Superior, o artigo $3^{\circ}$, parágrafo $2^{\circ}$ do Decreto-Lei no 869 de 12 de setembro de 1969 (que "Dispõe sobre a inclusão da Educação Moral e Cívica como disciplina obrigatória, nas escolas de todos os graus e modalidades, dos sistemas de ensino no País") estabelece que: "No sistema de ensino superior, inclusive pós-graduado, a Educação Moral e Cívica será realizada, como complemento, sob a forma de Estudos de Problemas Brasileiros, sem prejuízo de outras atividades culturais visando ao mesmo objetivo." Conforme afirmado no artigo $2^{\circ}$, "apoiando-se nas tradições nacionais" entre as finalidades dessa disciplina estava: "a defesa do princípio democrático, através da preservação do espírito religioso, da dignidade da pessoa humana e do amor à liberdade com responsabilidade, sob a inspiração de Deus". Cunha e Góes apontam que apesar de ser proclamada na época como "aconfessional, isto é, não vinculada a nenhuma religião e a nenhuma igreja", na prática a situação era outra:

(...) a incorporação das doutrinas tradicionais do catolicismo e de seus quadros não era sequer disfarçada nos textos e diretrizes da Comissão Nacional de Moral e Civismo, nem nos livros didáticos que ela aprovava para uso nas escolas. (...) Assim, ficavam afastadas todas as religiões afro-brasileiras, apesar de efetivamente praticadas por dezenas de milhões de pessoas, relegadas pelos moralistas e civilistas, à condição de resíduos de ignorância ou de curiosidades folclóricas. O mesmo acontecia com as crenças indígenas, apesar do cínico culto dos índios como os primeiros brasileiros. (2002, p. 74)

O Golpe Militar de 1964 impôs uma série de mudanças na legislação brasileira sobre educação (algumas, inegavelmente, já há muito tempo ansiadas, como a Reforma Universitária de 1968), que conferiu perfil diferente aos cursos superiores oferecidos na época?. Todas essas mudanças ocorridas no âmbito da legislação da educação básica e superior impuseram ao Curso Superior de História da Arte oferecido pelo IBA uma série de transformações. No entanto, 
acredita-se que a fusão dos Estados da Guanabara e do Rio de Janeiro no ano de 1975 e, principalmente, suas consequentes mudanças estruturais as quais conduziram à transformação do Instituto de Belas Artes em Escola de Artes Visuais (EAV), é que tenham gerado uma crise sem precedentes no Curso Superior de História da Arte oferecido por aquela instituição e que quase ocasionou sua extinção. Esse processo e seus debates foram noticiados em vários periódicos da época.

Em matéria publicada no Jornal do Brasil em 05 de dezembro de 1975, intitulada "História da Arte, sim ou não?", assinada por Emília Silveira e com fotos de Ari Gomes, trata das modificações ocorridas na instituição e que ameaçavam a existência do Curso Superior de História da Arte na estrutura da Escola de Artes Visuais Parque Lage (ex-Instituto de Belas Artes). Segundo a diretoria da escola da época (a saber: a cargo de Rubens Gerchman [1942-2008] entre 1975 e 1979), a disciplina História da Arte não seria eliminada do currículo dos cursos de formação artística. No entanto, a respeito da sobrevivência do curso superior a diretoria é taxativa:

O que termina é o curso superior dessa matéria, um antigo engodo em que os alunos infelizmente entravam. Não há oficialização, diploma ou qualquer continuidade no curso atual, para justificar sua manutenção. Os alunos matriculados vão poder concluir seu curso, mas não haverá novas matrículas. O que fizemos foi suprimir algo que, do ponto-de-vista cultural, já não existia.

A argumentação é dura e direta: não haveria condições favoráveis que justificassem a continuidade do curso. Talvez, a postura da diretoria da Escola seja também uma respostaprotesto à situação na qual se encontrava o curso: o ingresso da primeira turma se deu em 1961 e, entre 1963 e 1978, 181 alunos o concluíram (Processo UERJ 605/DAA/1980, Arquivo DEP/SR1, fl.8). Até o momento, no entanto, isso é mera especulação. Contudo, o que se pode observar é que a nova configuração da instituição ao tornar-se Escola de Artes Visuais (oferta de cursos livres, sem a exigência de pré-requisitos ou exames de admissão, sem a concessão de diplomas) aliada à fragilidade institucional do curso (tendo em vista a sua não-oficialização até então) e de sua não-existência "do ponto de vista cultural", deu início a um debate que se desdobrou pelos dois anos seguintes.

No início do ano de 1976, o problema retorna, sendo abordado em crônica assinada por Carlos Drummond de Andrade (1902-1987) intitulada "Diálogo no Parque", publicada igualmente no Jornal do Brasil de 09 de março de 1976. Nele, o autor descreve o encontro com uma "alma-penada": "um jovem de 20 anos, boa pinta, nada espectral e, segundo me confiou, candidato a matrícula em curso inexistente." O diálogo começa com uma interrogação curiosa ao jovem:

- Se o curso não existe, como é que você queria matricular-se nele? - perguntei-lhe.

- Não existe no real mas existe, ou melhor, existe sem existência, entende?

- Não.

- Nem eu. Mas as coisas agora são assim. O existente é impalpável, vigora o não existente, que como se existisse, inexistindo. (...)

- Ó alma penada, explique isso direito, para que eu também não acabe duvidando de minha concretude aqui e agora. 
- Vou tentar. Havia no Parque um Instituto de Belas-Artes, funcionando normalmente. Esse nome ficou demodé. Ninguém mais quer achar bela alguma coisa sobre a Terra, né? Belo é careta. Então as artes, de tempos a esta parte, passaram de belas a simplesmente visuais. Por enquanto são visuais. Amanhã serão palatais, intestinais, sei lá. Então o Instituto virou Escola de Artes Visuais, pelo processo geral de fusão, que manda fundir gregos e goianos. Um de seus cursos, aquele com que eu sonho, era o de História da arte. De quatro anos, para formação de professores da matéria. Este ano fui correndo me inscrever, mas quem disse? Não tinha matrícula. Quando abre? Não abre. Me explicaram que quem vinha fazendo o curso, no ano passado, continuará a fazer, mas tem de mudar-se para deus-me-livre, sem biblioteca e material pedagógico especializado, que ficarão no Parque. Engraçado, né? E quem não começou... desista. Então o curso foi extinto? Não. Apenas não se pode cursá-lo. Agora capisca? (1976, p. 5)

O diálogo prossegue. Além da insatisfação com relação à situação marginal do curso, há também o choque entre dois pensamentos diferentes a respeito tanto da história da arte e como da produção artística. O ensino artístico no IBA tinha como referência o ensino acadêmico, as "Belas Artes" como o próprio nome the confere. O novo projeto de ensino que se estabelece com a mudança para "Escola de Artes Visuais" se relaciona com uma posição mais afinada com a produção artística contemporânea. O próprio diretor da instituição, o artista Rubens Gerchman, gozava de reconhecimento e prestígio, tendo sido sua obra comentada pelo crítico Mário Pedrosa (1900-1981). Logo, não eram apenas questões burocráticas que estavam em jogo. Havia um choque entre gerações, entre compreensões divergentes a respeito do que era arte e, por conseqüência, do ensino artístico que seria oferecido pela instituição. Talvez, considerando o contexto histórico, a questão pudesse revelar duas posturas diante da sociedade: uma retrógrada, apegada a modelos tradicionais; outra vanguardista, que se lança para o novo. Isso se esclarece, por exemplo, na resposta dada pelo interlocutor da "almapenada" ao final do "Diálogo no Parque":

- Inocente, pouco importa que esse curso acabe ou continue morto-vivo. A questão é mais profunda, e prende-se a um conceito geral de vida, que está lavrando mundo afora. A palavra da moda é questionar, não na acepção de debater para esclarecer, mas na de pôr em dúvida, e finalmente, negar. Todos os valores, já não digo morais, que são contingentes por natureza, mas os intelectuais, que se baseiam no conhecimento, isto é, varridos da circulação. Varre-se tudo, em favor de nada. A vida perde o sentido, ou os múltiplos sentidos que the quisermos ou soubermos dar. Resta a anulação da sensibilidade e da consciência estética, até prática, o não pelo não, o sem sentido. Proibido o uso do gosto. Ausência de gosto e mau-gosto se unificaram. Com esse estado de espírito generalizado, a arte vira artiarte e, por último, coisa nenhuma. Ora, não havendo arte, você queria estudar história da arte? E não havendo história da arte, para que matrícula?

- Mas...

- Cale-se. Como alma-penada, na ilusão de um curso que não pode existir, independente de haver ou não a formalidade burocrática da matrícula, resigne-se à condição fantasmal. Não há nada a fazer. Se se restabelecesse o ensino da disciplina, seria para ensinar a você e a outras almas-penadas, outros tantos pobres-diabos, que a arte nunca existiu e ninguém precisa dela. Não reclame, como eu não estou reclamando. Vim aqui para contemplar estas últimas folhas 
verdes, este final de mundo antigo, ainda esplendoroso na limitação deste parque. Amanhã vão me cobrar taxa de natureza-morta, como já cobram a taxa de lixo. Bitributação injusta, pois só haverá lixo. E é possível que então apareça alguém para escrever (e ensinar) a história do lixo, única história talvez possível, e definitiva. (1976, p. 5)

Nos dias seguintes, foram publicadas várias notas de apoio e agradecimento enviadas à Drummond por alunos do curso em processo de extinção. Em 11 de março de 1976, no Caderno 1 do Jornal do Brasil, a matéria "Alunas da Escola de Artes Visuais exigem no Parque Lage direito de matrícula" noticia manifestações exaltadas de alunas irritadas em virtude da falta de diálogo com a atual diretoria da instituição (por elas alegada), além do descontentamento com a transferência das aulas do curso (para os antigos alunos, já que entre 1977 e 1978 não houve vestibular e ingresso de novas turmas) para o edifício da Escola de Teatro Martins Penna e, acima de tudo, da não-regulamentação do curso. Em 29 de março de 1976, quase duas semanas após a crônica de Drummond, é publicado na sessão "Cartas" (Jornal do Brasil, Caderno B) um abaixo-assinado encaminhado por Christina Scarabôtolo (aluna do curso) e mais 37 signatários, cuja reclamação premente era o reconhecimento do curso, já há mais de uma década existente.

Após esse período atribulado, nos parece que a situação somente se regulariza com a transferência e incorporação do curso à UERJ por meio de convênio celebrado entre esta e a Secretaria de Educação e Cultura (SEEC) do Estado do Rio de Janeiro, assinado em 05 de janeiro de 1978. Um grupo de trabalho da Faculdade de Educação da universidade foi então designado para acompanhar essa transição que se encontra documentada no processo UERJ 605/DAA/1980, disponível no Arquivo do Departamento de Orientação e Supervisão Pedagógica da Sub-Reitoria de Graduação (DEP/SR1). É afirmado na cláusula primeira do convênio que “O ESTADO (SEEC) dará prosseguimento ao Curso de História da Arte (...), o qual passará nos termos da Resolução n²3, de 23 de outubro de 1973, do Conselho Federal de Educação, a ser de Licenciatura Plena em Educação Artística - Habilitação em História da Arte" (Processo UERJ 605/DAA/1980, Arquivo DEP/SR1, fl.33-34). A partir de então, o curso passou a ser supervisionado pela Faculdade de Educação daquela universidade.

A mudança não foi apenas de ordem institucional, mas reverberou (por exemplo) na matriz curricular do curso. Com o tempo, as disciplinas pedagógicas passaram a ocupar uma parte significativa da formação profissional. No entanto, prevaleceu ainda o domínio da História da Arte Ocidental. Algumas mudanças com relação à nomenclatura de disciplinas voltadas para as produções artísticas e culturais fora desse eixo privilegiado chamam atenção. Por exemplo: as disciplinas "Arte Pré-Colombiana" e "Arte Primitiva (África Negra, Oceania e outras)". Na primeira há um problema fundamental: chamar "arte" a produção "pré-colombiana" é adotar o discurso colonizador, impondo-se um conceito europeu (produto de um determinado contexto histórico e cultural) a fenômenos cuja produção com ele não se articula. Já na segunda, o termo primitivo evidencia uma relação pejorativa com os fenômenos a serem estudados. Novamente tomando como referência o Ocidente, a África Negra, a Oceania e as "outras" aparecem como a parte do globo não civilizada, onde o tempo não passou, o progresso não foi possível, onde tudo se encontra no estado "natural", rudimentar.

Especula-se ainda que a mudança na nomenclatura de "Curso de História da Arte" para "Curso de Educação Artística - Habilitação em História da Arte" fez com que este caísse no 
esquecimento e, por anos, investigadores da área afirmassem categoricamente a inexistência de cursos de graduação em História da Arte.

Apesar de serem eventos que avançam significativamente nesse primeiro recorte temporal, alguns apontamentos merecem aqui ser relacionados para que se tornem mais compreensíveis.

Com a criação do Instituto de Artes, em 2002, o curso não apenas foi transferido da Faculdade de Educação, como se implantou nova reforma curricular que, segundo Conduru, visava "à atualização do curso, que permanecera muito similar por quatro décadas" (2007, p. 151). O curso passou a se chamar "Curso de Artes - Habilitação: Bacharelado e/ou Licenciatura em História da Arte" até 2006, quando são "formulados novos princípios, métodos e critérios para as disciplinas de história da arte" que orientarão teórica e criticamente o currículo implementado em 2009. São pressupostos dessa nova estrutura:

1. A eliminação da cronologia como forma de ordenação das disciplinas, através do recurso a um recorte conceitual que instigue cruzamentos temporais e espaciais, sem contudo fornecer um modelo de desdobramento para cada disciplina;

2. A necessidade de, no desdobramento de cada entrada conceitual, não se ater nem se centrar na arte do Ocidente;

3. Incluir a arte no Brasil na reflexão mais geral, de maneira a evitar diferenciações hierárquicas tradicionais;

4. Descartar narrativas totalizantes, problematizando o próprio ato de historiar e as histórias da arte existentes (princípios, objetos, métodos, processos, produtos). (Siqueira, 2009, p. 70.

Vários outros aportes seriam possíveis. No entanto, o breve espaço não permite infelizmente aprofundar análises iniciadas nos parágrafos anteriores. Também por acreditar que seja igualmente importante relacionar o contexto particular de criação do primeiro curso com um quadro geral nacional, mesmo que brevemente.

A criação do primeiro Curso Superior de História da Arte, no início da década de 1960, deu-se em uma conjuntura de significativas transformações na sociedade brasileira.

Segundo Cardoso e Novais, os anos 1950 foram marcados pela sensação de que faltava pouco, muito pouco para que, enfim, o Brasil se tornasse uma "nação moderna":

(...) alguns imaginavam até que estaríamos assistindo ao nascimento de uma nova civilização nos trópicos, que combinava a incorporação das conquistas materiais do capitalismo com a persistência dos traços de caráter que nos singularizavam como povo: a cordialidade, a criatividade, a tolerância. (1998, p. 560)

O desenvolvimento tecnológico e industrial entre os anos 1950 e 1970 impactou o cotidiano e a vida privada dos brasileiros (ou, ao menos, de parte da população). Era possível fabricar quase tudo no Brasil: aço, alumínio, petróleo e derivados (gasolina, óleo diesel, óleo combustível, asfalto, plástico, detergente, etc.). Além disso, cresceram e modernizaram-se a produção de cimento, vidro, papel, bem como a indústria de alimentos, têxtil, confecções, calçados, bebidas e móveis: 
Chegou o extrato de tomate; a lata de ervilha, de palmito, de milho, de legumes picados; o leite condensado; o leite em pó, alguns só para crianças; o creme de leite; o iogurte; novas espécies de biscoito e de macarrão; os achocolatados; a linguiça, a salsicha, a presuntada e os outros embutidos; o frango de granja toma o lugar do frango caipira, com grande perda de sabor; o mesmo acontece com os ovos; o queijo prato e a mussarela; a azeitona em lata e depois em vidro; as batatas chips; a aveia em lata, muito depois os cereais; os salgadinhos para aperitivo; o doce de lata, a goiabada, a marmelada, a bananada; o pêssego ou o figo ou a goiaba em calda, mais caros; o pão tipo Pullman, para fazer torradas ou sanduíches, agora em moda. (Cardoso e Novais, 1998, p. 565)

Brasília, a nova capital federal, inventada pelo arquiteto e urbanista Lúcio Costa (19021998), é fundada em 21 de abril de 1960. A dimensão monumental (material e simbólica) do "Plano Piloto" era a demonstração mais grandiosa e sintética daquilo que o então presidente Juscelino Kubitschek (1902-1976) denominou como "a vontade de progresso" no discurso em ocasião da sua inauguração. Brasília representava, portanto, a síntese e a expressão máxima da utopia de um Brasil moderno, que avançava irremediavelmente em direção ao futuro.

Considerando a produção artística da época, tendo como recorte Rio de Janeiro e São Paulo, é entre as décadas de 1950 e 1960 que germina e se desenrola as primeiras manifestações do projeto construtivo brasileiro. Alguns fatos esclarecem a atenção despertada pelo novo paradigma artístico: em 1951, os prêmios concedidos à escultura Unidade Tripartida, de Max Bill (1908-1994) e à tela Formas, de Ivan Serpa (1923-1973), bem como a premiação de Antônio Maluf (1926-2005) no concurso de cartazes da $1^{\text {a }}$ Bienal.

Sobre a relação entre as ideologias construtivas e o desenvolvimento cultural latino-americano entre as décadas de 1940 e 1960, Brito argumenta que elas

(...) encaixavam-se com perfeição nos projetos reformistas e aceleradores dos países do continente e serviram, até certo ponto, como agentes da libertação nacional ante o domínio da cultura européia, ao mesmo tempo em que significavam uma inevitável dependência desta. (1999, p. 52)

E prossegue:

Optar pela arte concreta no início dos anos 50 significava optar por uma estratégia cultural universalista e evolucionista. (...) O concretismo brasileiro tinha consciência de sua posição na linha de desenvolvimento da história da arte - ele se pretendia declaradamente um novo lance da sequência de uma busca das verdadeiras bases nas quais se calcava a pesquisa artística.

(Brito, 1999, p. 39)

O objetivo, a partir de então, dos grupos de artistas participantes desse discurso é a construção de uma nova arte, propositora de uma nova visualidade para um novo homem de um novo tempo.

Algo curioso é notar o descompasso entre a produção artística em questão e a história da arte que se "institucionaliza" no IBA (tendo em vista, por exemplo, o currículo elaborado). Se, por um lado, os concretistas e (mais tarde) os neoconcretistas reconheciam seu lugar particular, somente deles, na história da arte; por outro, o currículo do curso superior oferecido pelo IBA reforçava uma posição de desvantagem da produção da produção brasileira em relação à européia. 
Do ponto de vista institucional, são inaugurados o Museu de Arte de São Paulo Assis Chateaubriand (em 1947) e os Museus de Arte Moderna do Rio de Janeiro e de São Paulo (ambos em 1948). É realizada a $1^{\text {a }}$ Bienal Internacional de Arte de São Paulo, em 1951, que colocou (segundo Lourival Gomes Machado, diretor do MAM-SP e diretor artístico da mostra) a produção artística moderna brasileira em vivo contato com aquela do resto do mundo. Couto, ao tratar da esperança brasileira em se impor mundialmente, aponta que além do desejo de "se lançar definitivamente na era da industrialização" e de experimentar "um privilegiado no novo arranjo de nações", alimentado pelo acelerado desenvolvido econômico, acreditavase "na possibilidade de o país participar do debate cultural da época com uma contribuição significativa e original" (2004, p. 16):

Novos museus, voltados para a arte moderna, são então fundados, e assiste-se à difusão da arte abstrata nos grandes centros brasileiros. A criação das Bienais de São Paulo representa o ponto culminante desse processo de abertura e dessa tentativa de renovação das artes plásticas no país. (...) A amplitude da primeira Bienal do Museu de Arte Moderna de São Paulo, realizada em 1951, que contou com a participação de 20 delegações estrangeiras e apresentou mais de 1500 obras, atesta a intenção de seus promotores de incluir o país no circuito internacional de exposições, rivalizando com as Bienais de Veneza. Essa tentativa, na verdade, insere-se perfeitamente no projeto mais amplo de modernização da sociedade brasileira implementado pelo Estado, que procurava infundir, interna e externamente, a imagem do Brasil como uma das futuras potências mundiais e forte candidato a ocupar um lugar privilegiado no cenário artístico internacional. A idéia de que o país pudesse ameaçar, em um futuro próximo, a posição hegemônica de Paris como centro mundial das artes era defendida e propagada por personalidades de destaque no período. (Couto, 2004, pp. 16, 59-60)

Em setembro de 1959, foi realizado o Congresso Internacional Extraordinário de Críticos de Arte, da Associação Internacional de Críticos de Arte, ocorrido nas cidades de Brasília (ainda em construção), São Paulo e Rio de Janeiro, tendo como tema "A Cidade Nova - A Síntese das Artes." O Congresso reuniu arquitetos, urbanistas e críticos de arte que, segundo Cappello, exploraram "a experiência de Brasília como cidade nova e sua significação na cultura arquitetônica brasileira e sua expressão no território nacional" (2009, p. 4). Geraldo argumenta que, mesmo sendo considerado por algumas "vozes discordantes" "apenas uma estratégia de divulgação do programa de governo de Juscelino Kubitschek," o encontro Ihe pareceu "um dado importante para o processo de diagnóstico da formação da história e da crítica dos últimos 47 $a_{n o s}{ }^{9} \mathrm{em}$ nosso país, já que reuniu importantes nomes da arquitetura, assim como da história e da crítica de arte e arquitetura, tanto nacionais, quanto internacionais"10 (2007, pp. 542-543). Pouco mais de uma década depois da realização do Congresso, é fundado o Comitê Brasileiro de História da Arte, com o envolvimento de participantes do evento anterior (como Mário Barata (1921-2007) e Lúcio Costa (1902-1998).

Entre 1962 e 1963 são lançados compêndios de história da arte: o "História crítica de arte", obra em seis volume de José Pinto Fléxa Ribeiro (1884-1971); "História das Artes", obra em dois volumes de Carlos Felinto Cavalcanti (1909-s.d.). Uma curiosidade: além de participar do Congresso Internacional Extraordinário de Críticos de Arte, Carlos Cavalcanti foi professor do IBA, lecionando no Curso Superior de História da Arte. Carlos Octávio Fléxa Ribeiro (19141991), filho de José Pinto Fléxa Ribeiro, foi Secretário de Estado de Educação e Cultura da 
Guanabara entre os anos de 1960 e 1965, período de criação do curso, tendo o nome registrado (juntamente com o de Carlos Lacerda, governador do Estado da Guanabara naquela ocasião) no Decreto $n^{0} 1.525$ de 12 de fevereiro de $1963^{11}$. Acredita-se que a reincidência dos nomes citados possa revelar (mais adiante, no desenrolar da pesquisa em andamento) uma rede de relações institucionais e pessoais que melhor elucidem a conjuntura da criação do curso.

Se, por um lado, é possível questionar a relação direta e causal entre os acontecimentos elencados brevemente, a efervescência do período que antecede e que podem ter gerado a demanda para a criação do primeiro curso de graduação em história da arte, não se pode, por outro lado, não observá-los. Da mesma forma que, indiretamente, o golpe de 1964 e suas reformas educacionais impuseram uma série de mudanças ao curso (inclusive, ameaçando-o de extinção).

\section{Segundo Momento (de 1980 aos dias de hoje)}

As duas primeiras décadas do século XXI, no contexto brasileiro, têm sido de grandes avanços para o campo de ensino e pesquisa da história da arte nas universidades. Em um intervalo de tempo de menos de 5 anos foram criados mais quatro cursos de graduação na área, vinculados às seguintes instituições: Escola de Filosofia, Letras e Ciências Humanas da UNIFESP; à Escola de Belas Artes da UFRJ; ao Instituto de Artes da UFRGS; e ao Instituto de Artes da UnB.

Apesar de terem perfis muito diferentes, relacionados em parte à trajetória de cada uma das instituições de onde emergem, um característica comum os congrega: estão todos alocados em universidades federais. Esse fato não é mera coincidência. A criação desses cursos nos últimos anos se relaciona, com o desejo (particular e coletivo) de uma comunidade científica em processo de legitimação e que pretende convencer as outras de que "está em condições de dominar um conjunto de questões que até então estavam sob a jurisdição de outra comunidade" (Gavroglu, 2007, p. 187). Dispersa em outros campos de investigação, a quase total ausência de uma formação específica em História da Arte em nível de graduação no Brasil aponta para uma visão da história da arte como conteúdo secundário e complementar a outros campos de investigação e, por conseguinte, ao não reconhecimento de suas especificidades. Em parte, essa capacidade de articulação é inerente ao objeto da história da arte - o fenômeno artístico, o qual demanda obstinadamente diálogos em múltiplas direções. Inegável os benefícios advindos de uma abordagem transdisciplinar, porém, acredita-se que antes de se prosseguir na diluição das fronteiras, embrenhando-se em um labirinto de infinitas possibilidades, seja necessário retomar o fio de Ariadne: um exame profundo do ofício do historiador da arte. Salienta-se ainda que a criação desses cursos não só oportuniza uma formação de base mais qualificada, como também gera demanda de mão de obra. Logo, além de novos postos de emprego para profissionais já formados, estimula-se o desenvolvimento de centros de pesquisa, o que colabora para o fortalecimento da área.

Retomando, somente o desejo não bastaria. A criação e implantação dos cursos de graduação em História da Arte na última década foram oportunizadas diretamente pelo Programa de Apoio a Planos de Reestruturação e Expansão das Universidades Federais (Reuni) do Governo Federal, instituído durante o segundo mandato do então presidente da república Luiz Inácio Lula da Silva pelo Decreto $n^{\circ} 6.096$, de 24 de abril de 2007'2, uma das ações que integram o Plano de Desenvolvimento da Educação (PDE). O Reuni objetiva ampliar o acesso e a 
permanência na educação superior, tendo como meta dobrar o número de alunos nos cursos de graduação ao longo de uma década (o marco inicial é o ano de 2008) ${ }^{13}$.

Há outra particularidade em relação ao processo de criação e implantação desses cursos: com a única exceção daquele alocado na UNIFESP; todos os outros se encontram vinculados a unidade universitária voltada à formação artística. A situação revela características específicas da configuração do campo de pesquisa no Brasil: vinculados historicamente aos institutos de artes, é onde encontraram condições propícias de criação, implantação e desenvolvimento.

A questão do lugar da história da arte nas universidades brasileiras não é recente e, no entanto, não deixa de ser atual. Dois episódios podem esclarecer melhor a questão.

Retomando o caso da transferência do curso superior oferecido pelo IBA para a UERJ, o primeiro episódio se refere à carta encaminhada pela Professora Maria Violeta Coutinho Villas Boas em resposta às observações feitas pelo relator do processo em que a Faculdade de Educação da UERJ (da qual era diretora) submete à aprovação do Conselho Superior de Ensino e Pesquisa da UERJ um novo currículo para o Curso de Educação Artística - Habilitação em História da $A_{r t e}{ }^{14}$. Verifica-se por meio dessa carta uma divergência entre a professora e o relator sobre a qual área de conhecimento a História da Arte pertenceria. Assim redige a professora:

Quanto ao questionamento constante do sexto parágrafo sobre a vinculação do curso à Faculdade de Educação, independente de ter sido ele situado pelo CFE ${ }^{15}$ na área de Comunicação e Expressão e não de Estudos Sociais e, ainda, ter o mesmo curso o objetivo de formação do professor de Educação Artística, o exame cuidadoso do elenco das disciplinas que o compõem evidencia a predominância dos conteúdos artístico-pedagógicos e não histórico-pedagógicos.

A dúvida levantada talvez tivesse procedência se houvesse na UERJ um Instituto de Arte. Então, este sim se incumbiria da formação específica dos alunos. Na inexistência de uma unidade desta natureza, o corpo de professores da Escola de Artes Visuais da SEEC/RJ detém a responsabilidade desta formação, conforme a cláusula primeira do Convênio em vigor até dezembro de 1983.

Deve-se, ainda, colocar que todo o tratamento dado à Arte já é permeado pelo enfoque educacional, daí o acerto da vinculação do curso à Faculdade de Educação, pois que se visa à formação do professor de Educação Artística o qual buscará o desenvolvimento, pela educação, do potencial artístico da criança e do adolescente. (Processo UERJ 605/DAA/1980, Arquivo DEP/SR1, fl.168).

O segundo caso é carta encaminhada, em 2009, pela Associação Nacional de História (ANPUH) à Secretaria de Educação Superior do Ministério da Educação, cujo assunto era as "Mudanças nas denominações de alguns cursos." A carta respondia uma consulta pública proposta pelo Ministério da Educação (a qual esteve disponível até o dia 16 de outubro de 2009) para a constituição do proposto "Referenciais Nacionais dos Cursos de Graduação de Bacharelados e Licenciaturas", que pretendia "contribuir para organizar as ofertas de cursos superiores, uniformizando denominações para conteúdos e perfis similares, de modo a produzir convergências que facilitem a compreensão por todos os segmentos interessados na formação superior, sem inibir possibilidades de contemplar especificidades demandadas por regiões ou setores laborais do País". De acordo com o Ministério da Educação, a partir da constatação da existência de uma variedade de denominações para os cursos de graduação e "com o auxílio 
de profissionais e pesquisadores que atuam nas áreas, foi realizado um estudo que resultou em uma proposta de nomenclatura que adapta as denominações atualmente existentes" 16. O que chama atenção nos Referenciais Nacionais é a não contemplação e o desaparecimento das graduações em História da Arte na convergência forçada, aglutinação e achatamento da área em outras (a saber: Artes Visuais - Bacharelado e Licenciatura; Dança - Bacharelado e Licenciatura; Música - Bacharelado e Licenciatura; História - Bacharelado e Licenciatura)17. O trecho a seguir, uma edição da carta integral18, esclarece o posicionamento da ANPUH diante da proposta do Ministério:

Compreendendo a necessidade de padronização dos referenciais ou nomenclaturas dos cursos de graduação, evitando a proliferação ${ }^{19}$ de cursos com nomenclaturas que dificultam a inserção do egresso no mercado de trabalho, a avaliação e acompanhamento de seus projetos político-pedagógicos e a escolha dos estudantes na hora do ingresso na Universidade.

(...) Aplaudindo o fato de que as denominações tradicionais em nossa área (História - Bacharelado e História - Licenciatura) estão sendo valorizadas e reafirmadas na contramão da emergência de cursos que não têm uma definição clara do perfil do egresso que quer formar, dos temas a serem abordados na formação e em que áreas o egresso poderá atuar.

A ANPUH - Associação Nacional de História vem fazer as seguintes ponderações a respeito das mudanças que estão sendo propostas nas denominações de alguns cursos e que são indicados para convergirem para as denominações tradicionais em nossa área:

(...) concordamos que não se pode permitir a proliferação de cursos em nível de Graduação que representam apenas um recorte, uma especialização em nossa área, o que é pertinente para cursos em nível de Pós-Graduação. Por isso concordamos que cursos com denominações como História da Arte e História, Teoria e Crítica da Arte devam convergir para a denominação História - Bacharelado e História - Licenciatura dependendo se o perfil do egresso que se quer formar se destina ao ensino ou a atuação profissional específica em instituições que lidam com objetos artísticos. Neste caso é indispensável que o curso venha perder o caráter de especialização que ele tem, verificando se seu projeto político-pedagógico contempla os componentes curriculares formadores do profissional de História. [grifo nosso]

Em ambos os casos, guardadas as devidas proporções, não há um esforço de compreensão sobre a história da arte em suas particularidades. A História da Arte é assim reafirmada ora como campo de saber secundário, disciplina complementar nas matrizes curriculares dos cursos de graduação em Artes (em suas diversas linguagens) como componente educativo para a formação do "artista"; ora como subcategoria da História. De todo modo, o desenvolvimento de uma formação profissional específica mostrou-se mais propício nos "Institutos de Artes" do que no território reservado institucionalmente às "Ciências Humanas". É importante destacar que não são raros os casos em que há uma ausência total de qualquer disciplina curricular obrigatória ou eletiva que contemple esses conteúdos específicos nos cursos de História.

A polêmica ainda não se encerrou. Ao longo do ano de 2013 houve uma ampla discussão a respeito do Projeto de Lei $n^{\circ}$ 4.699/2012, do senador Paulo Paim (Partido dos Trabalhadores PT), que regulamenta a profissão de historiador e "estabelece os requisitos para o exercício da atividade profissional e determina o registro em órgão competente". Segundo o Artigo $2^{\circ}$ do $\mathrm{PL}$ n 4.699/2012, "é livre o exercício da atividade profissional de historiador, desde que atendidas 
as qualificações e exigências estabelecidas nesta Lei", que são esclarecidas no Artigo $3^{\circ}$. De acordo com ele, o exercício da profissão seria restrito a portadores de:

I - diploma de curso superior em História, expedido por instituição regular de ensino;

II - diploma de curso superior em História, expedido por instituição estrangeira e revalidado no Brasil, de acordo com a legislação;

III - diploma de mestrado ou doutorado em História, expedido por instituição regular de ensino superior, ou por instituição estrangeira e revalidado no Brasil, de acordo com a legislação.

Houve uma grande comoção da parte dos profissionais de "outras histórias", com formações em campos muito diversos e que não se sentiu representada por esse Projeto de Lei, o que não é surpreendente ${ }^{20}$.

Considerando particularmente a formação do historiador da arte brasileiro, em comunicação apresentada no XXVI Colóquio do Comitê Brasileiro de História da Arte (2006), a Professora Dra. Denise Gonçalves da Universidade Federal de Viçosa (UFV) afirmava que grande parte dos historiadores da arte brasileiros preencheu importantes lacunas de sua formação apenas na pós-graduação. Durante muito tempo (e ainda hoje), a formação do historiador da arte e, por conseguinte, as pesquisas científicas por esse sujeito desenvolvidas, diluíam-se nos mais diversos programas de pós-graduação. Assim, segundo afirma Gonçalves,

(...) o ensino da história da arte aqui, salvo poucas exceções, aparece como complemento a outras disciplinas nos cursos de graduação, o que faz com que nós, historiadores de hoje, tenhamos formação em outras áreas - história, filosofia, arquitetura, letras, etc. (2007, p. 97)

A conseqüência disso, argumenta Gonçalves,

é que em geral a pós-graduação precisa suprir essa deficiência antes de cumprir o seu papel que é o de desenvolver estudos especializados sobre temas específicos, e isso acaba por comprometer a produção das pesquisas na área. (2007, p. 102)

Apesar da polêmica, um aspecto merece ser salientado. O primeiro deles é que a questão relaciona-se com o processo de formação, reconhecimento e legitimação de uma "nova comunidade científica" que, como afirma Gavroglu,

(...) faz-se em detrimento de uma outra, retirando-lhe privilégios sociais e elementos ideológicos. Por isso, os processos de formação das novas comunidades científicas nem sempre são bem-vindos por parte dos membros de outras comunidades já formadas, uma vez que com a formação da nova comunidade, são afetados interesses não só materiais mas também intelectuais. Assim, a história da formação de uma nova comunidade científica pode envolver períodos de forte tensão e, muitas vezes, de violência, uma vez que, em última análise, a criação de uma comunidade conduz, essencialmente, a uma redistribuição de poder, não só sobre os homens, mas também sobre as idéias que os homens "administram". (2007, p. 187) 
Parece oportuno aqui levantar a seguinte questão: qual a necessidade e as implicações de se delimitar ou não um território específico para a história da arte, pensando em uma época em que as fronteiras encontram-se cada vez mais fragilizadas pela necessidade da substituição de um sistema disciplinar por uma postura mais permeável? A perspectiva pós-disciplinar, inclusive, pode em muito contribuir para a investigação do objeto de estudo da história da arte - o fenômeno artístico, que impõe à história da arte um permanente estado de constante diligência para que não seja absorvida em definitivo por outras disciplinas científicas. Para que se possa compreender os fundamentos e a validez científica dos procedimentos teóricos e práticos da história da arte, é necessário que se empreenda antes uma revisão de seus métodos (Arenas, 1986, p. 15). E é aí que chegamos ao ponto: desde a década de 1980, a História da Arte tem sido marcada por uma profunda autorrevisão, resultado de uma crise "oriunda da perda de especificidades de seu objeto de estudo e da ausência de paradigmas" (Kern, 1999, p.107). No entanto, apesar do estado de crise, de tensão, se houve uma resposta forte e incômoda da parte, por exemplo, dos Historiadores da Arte ao PL n 4.699/2012, é sinal que o campo de pesquisas se encontra em um estado de maturidade e de autorreconhecimento de suas especificidades. E isso se evidencia em outros dados contextuais.

Desde a década de 1990, além da criação de diversos museus (inclusive com a criação do Instituto Brasileiro de Museus, em 2009), vêm sendo realizadas "grandes exposições" de arte com recordes de público. Se, por um lado, o fato se relaciona também com uma lógica socioeconômica de valorização do chamado "capital cultural", por outro lado é evidente que há a geração de uma demanda de profissionais aptos a atuarem nesses espaços.

As últimas décadas também assistiram a uma expansão do mercado editorial voltado para as artes, com a inauguração de importantes publicações acadêmicas, como as revistas: Gávea ${ }^{21}$, Porto Arte ${ }^{22}$, Arte\&Ensaios ${ }^{23}$, a Revista de História da Arte e Arqueologia ${ }^{24}$ e a Concinnitas ${ }^{25}$, apenas para citar algumas. Além disso, a publicação de anais de eventos científicos e, mais recentemente, a disponibilização desse material bibliográfico no meio digital contribui para a formação, circulação de informações e intercâmbio de discussões. Ressaltar ainda o aumento significativo no número de programas de pós-graduação (especialização, mestrado e doutorado) na área. Esse conjunto de referências nos faz supor que a criação de cursos de graduação em história da arte emerge como a consolidação de um campo de investigação científica.

\section{CONCLUSÃO}

Após uma breve revisão da instituição da História da Arte no Brasil a partir dos cursos de graduação, é possível avaliar que a história da arte, enquanto disciplina científica, encontra-se em um estado de crise. Etimologicamente, a palavra "crise" tem sua origem no termo grego krísis, que indica um estado de incertezas, de vacilação, de tensão, de risco. No entanto, por outro lado, ela também aponta para a necessidade urgente de uma tomada de posição, uma decisão, de mudança súbita: "um momento de desequilíbrio sensível, um estado de transição entre duas fases assinaláveis, nas quais vai se decidir uma transformação onde ainda não está decidida" (Durozoi e Roussel, 1993, p. 111).

Há quase três décadas, Arenas já contemplava o mesmo problema em obra dedicada à teoria e à metodologia da história da arte e assim argumentava a respeito da questão: 
Existe a consciência de que a história da arte se encontra em um momento de crise: crise ante a objetividade de sua importância como uma ciência da arte e crise ante ao perigo de ser absorvida por outras disciplinas. Em qualquer caso, podemos aceitar que se trata de uma crise de crescimento, de auto-afirmação, que consiste em algo muito positivo. (1986, p. 16)

Sobre a cientificidade da história da arte, alguns apontamentos são indispensáveis. Arenas divide sua obra "Teoria e Metodologia da História da Arte" em três partes. Na primeira delas, intitulada "A história da arte como ciência", o autor trata da importância do exame profundo dos modos de historiar e dos critérios científicos usados na história da arte, relacionando-o com a crise pela qual a história da arte passa desde o último quarto do século XX. Além disso, trata do objeto de estudo da história da arte (os fenômenos artísticos), bem como de seus objetivos (1986, pp. 13-38). No entanto, é necessário esclarecer que considerar a história da arte como ciência é um terreno bastante movediço e controverso. Deve-se ter em vista que nem mesmo sobre a história (da qual a história da arte descende, tendo reclamado sua autonomia enquanto disciplina universitária autônoma no final do século XIX) é possível afirmar categoricamente que se trata de uma ciência. Sobre a contenda, Le Goff afirma:

a história não é uma ciência como as outras - sem contar com aqueles que não a consideram uma ciência. (...) A contradição mais flagrante da história é sem dúvida o fato do seu objeto ser singular, um acontecimento, uma série de acontecimentos, de personagens que só existem uma vez, enquanto que o seu objetivo, como o de todas as ciências, é atingir o universal, o geral, o regular. (1990, pp. 17-33)

Refletindo a respeito do conceito de ciência, Magalhães disserta sobre as dificuldades de defini-lo rigorosamente, afirmando que essas

(...) dificuldades dependem não só da natureza dessas atividades, bastante fluídas, mas também de qual seja o posicionamento filosófico e ideológico de quem tenta defini-las e que nem sempre se encontra explicitado. (2005, p. 86)

No entanto, tendo em vista os propósitos por ele pretendidos, afirma que (...) ciência é um conhecimento crítico generalizante, expresso implícita ou explicitamente em termos causais, que buscam entender o mundo em que vivemos (incluindo o próprio homem), ou seja, a realidade, em qualquer nível. (2005, p. 88)

Ao tratar do caráter científico das "ciências sociais", afirma a complexidade de compreender a história tendo em vista tal definição, considerando-a um caso complexo: "se por um lado utiliza conhecimentos e métodos científicos (...), a sua ênfase é tratar do homem como individualidade, mesmo quando estuda coletividades." Logo, "a história é irrepetível em termos de eventos e, portanto, não-generalizável nesse sentido" (2005, p. 90). A história da arte é igualmente irrepetível. Os fenômenos artísticos, mesmo quando estudados em conjunto, comparativamente, em diálogo com outros fenômenos (contemporâneos ou não), são tratados igualmente como fatos únicos.

Considerando a autonomia do campo, apesar de não ser recente, a história da arte no Brasil esteve atrelada como disciplina complementar ao ensino artístico desde que seu ensino se tornou obrigatório na Academia Imperial de Belas Artes, em meados do século 
XIX. Era necessária ao artista para sua formação. Isso pode ser observado no fato de a maior parte dos cursos de graduação em história da arte no Brasil terem se desenvolvido em centros de pesquisa voltado para, a princípio, o ensino das artes. Ao mesmo tempo em que foi terreno fecundo para o desenvolvimento da disciplina, algo não viabilizado (por exemplo) entre as ciências humanas, esta particularidade aponta mais uma vez para o seu papel coadjuvante. Enquanto campo de pesquisa autônomo, sua existência ainda é muito recente e ainda peleja para se afirmar.

Os dois momentos recortados e apresentados neste artigo demonstram a ambigüidade com relação à necessidade da história da arte. Se, por um lado, a criação do curso superior no Instituto de Belas Artes foi recebida com entusiasmo, por outro, até sua transferência para a Universidade do Estado do Rio do Janeiro sua situação não havia sido regularizada. Davase início a uma formação profissional (e de um campo de atuação profissional, de ensino e pesquisa) em uma instituição legítima, mas sem o reconhecimento de fato (e "diplomado") da importância da área. A questão mal resolvida de outrora, retorna com a criação dos novos cursos nos últimos anos, quando os cursos de graduação em história da arte são criticados como uma especialização precoce, como uma espécie de organismo estranho que se prolifera e deve ser contido.

Por isso, é momento oportuno para que se questione: qual história da arte desejamos projetar hoje no Brasil? Acredita-se que a atual problematização do fazer história da arte no Brasil expressa, por exemplo, através dos currículos dos cursos de formação das universidades e dos debates que com eles dialogam, tenha relação com o amadurecimento do campo. Propõe-se assim que o reconhecimento das especificidades e limitações historiográficas da arte possa ajudar a compreender o que significa hoje produzir história da arte no Brasil, bem como criar condições fecundas para que se possa prosseguir a partir de tais questionamentos.

\section{NOTAS}

1 Brito, Ronaldo (2005, pp. 139-151).

2 Adaptação de trecho extraído do capítulo "A dedicatória" da obra "Fragmentos do discurso amoroso" de Roland Barthes, o qual é transcrito a seguir: "(...) o outro está inscrito, ele se inscreveu no texto, deixou aí seu rastro múltiplo" (1985, p. 69).

3 Oficialmente, de acordo com o Instituto Brasileiro de Geografia e Estatística (IBGE), o Brasil é dividido em cinco regiões, a partir de suas características econômicas, sociais e políticas: Norte, Nordeste, Centro-Oeste, Sudeste e Sul. Para além das demarcações regiões oficialmente estabelecidas e reconhecidas, a divisão geoeconômica do território brasileiro proposta pelo geógrafo Pedro Pinchas Geiger, já na década de 1960 aponta para três grandes complexos regionais: o Centro-Sul (industrial, polarizador), o Nordeste (agropecuário) e a Amazônia (extrativista). O Complexo Regional Centro-Sul abarcaria estados das regiões Sudeste e Sul, além de estados (integral ou parcialmente) da região Centro-Oeste e o Distrito Federal.

4 Segundo dados do IBGE, em 2011, cinco estados concentravam 65,2\% do PIB: São Paulo (32,6\%), Rio de Janeiro (11,2\%), Minas Gerais (9,3\%), Rio Grande do Sul (6,4\%) e Paraná (5,8\%). Todos se encontram, considerando a divisão proposta por Pedro Pinchas Geiger, no Complexo Regional Centro-Sul. Informações sobre a concentração do PIB disponíveis em: http://saladeimprensa.ibge.gov.br/noticias?view=noticia\&id=1\&b usca=1\&idnoticia=2522. (Acesso em: 24 de novembro de 2013).

5 Desde o início do processo de colonização, o Brasil (Colonial, Imperial e Republicano) já teve três capitais: Salvador, na Bahia, entre 1549 e 1763; Rio de Janeiro, capital entre 1763 a 1960; Brasília, desde 1960 até os dias de hoje. Com a transferência da capital federal para Brasília, o antigo Distrito Federal foi convertido em 
Estado da Guanabara, cuja capital era a cidade do Rio de Janeiro. Em 1975, no entanto, ocorre a fusão dos Estados da Guanabara e do Rio de Janeiro. Os motivos apontados para isso são vários, entre eles: como uma forma desenvolver a região de uma forma mais uniforme, tendo em vista a diferença de investimentos e arrecadação entre a cidade-estado da Guanabara (atual município do Rio de Janeiro) e o Estado do Rio de Janeiro (a primeira com mais recursos, o segundo marcada por uma carente infra-estrutura); como forma de controlar o partido de oposição que se fazia mais presente na Guanabara do que em território fluminense.

6 Em artigo, Conduru afirma a existência da disciplina "História da Arte das Américas." No entanto, os documentos pesquisados até o momento não apontam a existência de tal disciplina, ao menos não no início imediato do curso. A questão da existência ou não de uma disciplina específica sobre a produção artística das "Américas" permanece como problema a ser averiguado.

7 São elencados alguns exemplos. A Lei n 5.540 de 28 de novembro de 1968, a qual fixava normas de organização e funcionamento do ensino superior e sua articulação com a escola média, além da indissociabilidade entre ensino e pesquisa, afirmava que o ensino superior "será ministrado em universidades e, excepcionalmente, em estabelecimentos isolados, organizados como instituições de direito público ou privado". Mais adiante, a Lei n5.692 de 11 de agosto de 1971, mais conhecida como Lei de Diretrizes e Bases da Educação Nacional, tornou obrigatória a inclusão de Educação Artística (além de Educação Moral e Cívica, Educação Física e Programas de Saúde) nos currículos plenos dos estabelecimentos de $1^{\circ}$ e $2^{\circ}$ graus (Artigo $7^{\circ}$ ). Citam-se ainda as Indicações do Conselho Federal de Educação (Indicação n²2/73, de 08 de fevereiro de 1973: Formação do Magistério - Princípios e normas a observar na organização dos cursos de Licenciatura; Indicação n²3/73, de 08 de fevereiro de 1973: Cursos e Habilitações para as Licenciaturas da área de Educação Geral; Indicação n³6/73, de 07 de agosto de 1973: Mínimos de Conteúdo e Duração a observar na organização do Curso de Licenciatura em Educação Artística) e a Resolução n²3, de 23 de outubro de 1973, a qual fixou os mínimos conteúdos e duração a observar na organização do Curso de Licenciatura em Educação Artística (Processo UERJ 605/DAA/1980, Arquivo DEP/SR1, fl.09).

8 A transferência da capital já era pauta antiga, com mais de século de existência. As primeiras discussões sobre a interiorização da capital colonial, em meados do século XVIII. Cita-se ainda a existência de um dispositivo na Primeira Constituição Republicana de 1891, que previa a mudança da Capital Federal do Rio Janeiro para o interior do país.

9 Lembrando que Geraldo apresenta a comunicação no XXVI Colóquio do Comitê Brasileiro de História da Arte, em 2006.

10 Ainda segundo Geraldo, "estiveram no encontro os arquitetos Richard Neutra e Aero Saarinen, os artistas, críticos e historiadores Tomás Maldonado, Meyer Schapiro, Willian Holford, Bruno Zevi, Gillo Dorfles e Giulio Carlo Argan, que dialogaram com Lúcio Costa, Oscar Niemeyer, Mario Pedrosa, Mario Barata, Flexa Ribeiro, Carlos Cavalcanti, Flavio da Aquino, Ferreira Gullar e Fayga Ostrower, entre outros, totalizando 47 pessoas" (2007, p.542).

11 Fonte: http://www2.camara.gov.br/deputados/pesquisa/layouts_deputados_biografia?pk=122737\&tipo=0 (Acesso em: 01 de dezembro de 2013).

12 O Decreto n 6.096, de 24 de abril de 2007, que institui o Programa de Apoio a Planos de Reestruturação e Expansão das Universidades Federais - REUNI, encontra-se disponível em: http://www.planalto.gov.br/ ccivil_03/_Ato2007-2010/2007/Decreto/D6096.htm (Acesso em: 23 de novembro de 2013).

13 Informações sobre o Reuni disponíveis em: http://portal.mec.gov.br/index.php?ltemid=1085 (Acesso em: 23 de novembro de 2013).

14 A carta, que não está datada, integra o Processo UERJ 605/DAA/1980, Arquivo DEP/SR1. O parecer, apesar de citado e ter motivado uma resposta da professora, não integra o processo e não nos foi possível ainda o acesso a ele.

\section{A sigla CFE significa Conselho Federal de Educação.}

16 Informações disponíveis em: http://portal.mec.gov.br/index.php?option=com_content\&view=article\&id=1381 2: consulta-publica-dos-referenciais-nacionais-dos-cursos-de-graduacao\&catid=191: sesu\&ltemid=994 (Acesso em: 01 de dezembro de 2013).

17 Os quadros de "Convergência de Denominação (De ® Para)" se encontram ainda hoje disponíveis no site do Ministério da Cultura, divididos por áreas, sendo que: a. Área "Comunicação e Artes" em: http://portal.mec. gov.br/dmdocuments/consulta_artes.pdf; b. Área "Humanidades" em: http://portal.mec.gov.br/dmdocuments/ consulta_humanidades.pdf (Acesso em 01: de dezembro de 2013). 
18 A carta "Mudanças nas denominações de alguns cursos" se encontra disponível integralmente em: http:// www.anpuh.org/conteudo/view? ID_CONTEUDO=314 (Acesso em: 01 de dezembro de 2013).

19 No Brasil, entre vários significados, o termo proliferação é usado comumente para indicar o crescimento rápido, anormal, sem controle de algo ou alguma coisa (ex.: "Quando o poder publico não atua, o crime se prolifera"). Tendo em vista ocorrências relacionadas à Saúde Pública, é usado para indicar a rápida reprodução de agentes causadores de doenças (ex.:"As chuvas de verão aumentam o risco de proliferação do mosquito transmissor da dengue").

20 No site do Comitê Brasileiro de História da Arte é possível acessar uma série de cartas propostas em repúdio ao Projeto de Lei no 4.699/2012. Disponível em: http://www.cbha.art.br/carta_deputados_lei4699_2012.html (Acesso em: 01 de dezembro de 2013).

21 A Revista Gávea foi uma revista semestral do Curso de Especialização em História da Arte e Arquitetura no Brasil do Departamento de História da Pontifícia Universidade Católica do Rio de Janeiro, publicada de 1985 a 1997.

22 A Revista Porto Arte é uma revista semestral do Programa de Pós-Graduação em Artes Visuais do Instituto de Artes da Universidade Federal do Rio Grande do Sul, publicada desde 1990. Artigos disponíveis on-line em: http://seer.ufrgs.br/index.php/PortoArte/index (Acesso em: 01 de dezembro de 2013).

23 A Revista Arte\&Ensaios é uma revista semestral do Programa de Pós-Graduação em Artes Visuais da Escola de Belas Artes da Universidade Federal do Rio de Janeiro, publicada desde 1993. Artigos disponíveis on-line em: http://www.ppgav.eba.ufrj.br/producao-academica/arte-ensaios/ (Acesso em: 01 de dezembro de 2013).

24 A Revista de História da Arte e Arqueologia é uma revista semestral do Centro de História da Arte e Arqueologia, da Universidade Estadual da Campinas, publicada desde 1994. Artigos disponíveis on-line em: http://www.unicamp.br/chaa/rhaa/ (Acesso em: 01 de dezembro de 2013).

25 A Revista Concinnitas é uma revista semestral do Instituto de Artes da Universidade do Estado do Rio de Janeiro, criada em 1996 e que a partir de 2005 encontra-se vinculada ao Programa de Pós-Graduação em Artes do Instituto de Artes da mesma universidade. Artigos disponíveis on-line em: http://concinnitas.kinghost.net/ index.cfm (Acesso em: 01 de dezembro de 2013).

\section{REFERÊNCIAS}

Andrade, Carlos Drummond de. "Diálogo no Parque". Jornal do Brasil, Rio de Janeiro, 09 de março de 1976, Caderno B, 5 http://memoria.bn.br/DocReader/docreader.aspx?bib=030015_09\&Pag Fis=136615. (Acesso em: 21 de dezembro de 2013).

Arenas, José Fernández. Teoría y metodología de la historia del arte. Barcelona: Anthropos, 1986.

Barthes, Roland. Fragmentos do discurso amoroso. Rio de Janeiro: Francisco Alves, 1985.

Belting, Hans. O fim da história da arte: uma revisão dez anos depois. São Paulo: Cosac Naify, 2006.

Brito, Ronaldo. Neoconcretismo: vértice e ruptura do projeto construtivo brasileiro na arte. São Paulo: Cosac Naify, 1999.

Brito, Ronaldo. "Fato Estético e Imaginação Histórica". Em Experiência Crítica - textos selecionados: Ronaldo Brito. coord. gral. Sueli de Lima. São Paulo: Cosac Naify, 2005. 139151.

Cappello, Maria Beatriz Camargo. “Congresso Internacional de Críticos de Arte 1959. Difusão nas Revistas Internacionais e Nacionais Especializadas". Em $8^{\circ}$ Seminário Docomomo Brasil. Cidade Moderna e Contemporânea: Síntese e Paradoxo das Artes. Rio de Janeiro: 2009. http://www.docomomo.org.br/seminario\%208\%20pdfs/080.pdf. (Acesso em: 30 de novembro de 2013).

Cardoso, João Manuel e Novais, Fernando. "Capitalismo tardio e sociabilidade moderna". Em História da vida privada no Brasil: contrastes da intimidade contemporânea. Vol. 4. coord. gral. Fernando Novais e Lilia Moritz Schwarcz. São Paulo: Companhia das Letras, 1998. Coleção "História da vida privada no Brasil". 
Certeau, Michel de. A escrita da história. Rio de Janeiro: Forense Universitária, 2007.

Conduru, Roberto. "Do silêncio à marginalização: arte e África, IBA e UERJ". Em Anais do XXVI Colóquio do Comitê Brasileiro de História da Arte. coord. gral. Marília Andrés Ribeiro e Maria Izabel Branco Ribeiro. Belo Horizonte : C/Arte, 2007. pp.154-161.

Couto, Maria de Fátima Morethy. Por uma vanguarda nacional. A crítica brasileira em busca de uma identidade artística (1940-1960). Campinas: Editora da Unicamp, 2004.

Cunha, Luiz Antônio e Goés, Moacyr de. O golpe na educação. Rio de Janeiro: Jorge Zahar Ed., 2002.

Durozoi, Gérard e Roussel, André. Dicionário de Filosofia. Campinas: s.e., 1993.

Gavroglu, Kostas. O Passado das Ciências como História. Porto: Porto Editorial, 2007.

Geraldo, Sheila Cabo. "A crítica internacional e o Brasil sob o signo da arte". Em Anais do XXVI Colóquio do Comitê Brasileiro de História da Arte. coord. gral. Marília Andrés Ribeiro e Maria Izabel Branco Ribeiro. Belo Horizonte : C/Arte, 2007. pp.154-161.

Gonçalves, Denise. "A formação do historiador de arte no Brasil: possibilidades de renovação da disciplina sob o olhar contemporâneo". Em Anais do XXVI Colóquio do Comitê Brasileiro de História da Arte. coord. gral. Marília Andrés Ribeiro e Maria Izabel Branco Ribeiro. Belo Horizonte : C/Arte, 2007. pp.85-95.

Instituto Brasileiro de Museus. Museus em números / Instituto Brasileiro de Museus. [online]. Brasília: Instituto Brasileiro de Museus, 2010. http://mineiropt.com.br/media/uploads/ publications/museus_numeros.pdf. (Acesso em: 24 de novembro de 2013).

Instituto Brasileiro de Museus. Museus em números / Instituto Brasileiro de Museus. [on-line]. Vol. 1. Brasília: Instituto Brasileiro de Museus, 2011. http://www.museus.gov.br/wp-content/ uploads/2011/11/museus_em_numeros_volume1.pdf. (Acesso em: 24 de novembro de 2013).

Instituto Brasileiro de Museus. Museus em números / Instituto Brasileiro de Museus. [on-line]. Vol. 2. Brasília: Instituto Brasileiro de Museus, 2011. http://www.museus.gov.br/wp-content/ uploads/2011/11/Museus_em_Numeros_Volume_2A.pdf (Parte 1). http://www.museus.gov.br/ wp-content/uploads/2011/11/Museus_em_Numeros_Volume_2B.pdf (Parte 2). (Acesso em: 24 de novembro de 2013).

Kern, Maria Lúcia Bastos. "Historiografia da arte e o debate sobre a crise da disciplina". Em Anais do $13^{\circ}$ Encontro Nacional da Associação Nacional de Pesquisadores em Artes Plásticas "Arte em Pesquisa: especificidades", Vol. 1. coord. gral. Maria Beatriz Medeiros. Brasília: ANPAP, 2004. 205-210.

Kern, Maria Lúcia Bastos. “Os impasses da História da Arte: interdisciplinariedade e/ou especificidade do objeto de estudo?" Revista da Sociedade Brasileira de Pesquisa em História, n. 16. Curitiba: SBPH (1999): 107-113.

Le Goff, Jacques. História e Memória. Campinas: Editora da Unicamp, 1990.

Leite, José Roberto Teixeira. "A História da Arte no IBA". Diário de Notícias, Rio de Janeiro, 21 de fevereiro de 1963, Segunda Seção, 3, Coluna Vida das Artes http://memoria.bn.br/DocReader/ DocReader.aspx?bib=093718_04\&PagFis=27825. (Acesso em: 21 de dezembro de 2013).

Magalhães, Gildo. Introdução à metodologia científica: caminhos da ciência e tecnologia. São Paulo: Ática, 2005.

Silveira, Emília. "História da Arte, sim ou não?". Jornal do Brasil, Rio de Janeiro, 05 de dezembro de 1975, Caderno B, p.10. http://memoria.bn.br/DocReader/DocReader.aspx?bib=030015_09\&PagF is $=132353$. (Acesso em: 21 de dezembro de 2013).

Siqueira, Vera Beatriz. "Curso de bacharelado em História da Arte - UERJ". Em Anais do XXIX Colóquio do Comitê Brasileiro de História da Arte. Rio de Janeiro: Comitê Brasileiro de História da Arte, CBHA, 2009. 67-76. 


\section{Cómo citar este artículo:}

Amaro, Danielle. "O lugar da História da Arte no Brasil: breve revisão da instituição da história da arte no Brasil a partir dos cursos de graduação. Cuadernos de Música, Artes Visuales y Artes Escénicas, 9 (1), 69-93, 2014, http://dx.doi.org/10.11144/ Javeriana.MAVAE9-1.olha 
